\title{
Recovery of Metals from Mine Wastes: The Effect of Biochar-Fe Composites in the Immobilization of Arsenic
}

\author{
M. L. Álvarez ${ }^{1} \cdot$ G. Gascó ${ }^{2} \cdot$ R. Rodíguez-Pacheco ${ }^{3} \cdot$ J. Paz-Ferreiro $^{4} \cdot$ A. Méndez ${ }^{1}(\mathbb{0}$
}

Received: 22 October 2021 / Accepted: 5 January 2022 / Published online: 3 February 2022

(c) The Author(s) 2022

\begin{abstract}
Mine wastes are a major environmental problem of main mines activities. However, in recent years, related to the circular economy strategy, some of these wastes have been considered as secondary source of raw materials. Generally, metal's content show low concentrations and their recovery made the development of cheap and sustainable technologies necessary. The main objective of the present research is to study the potential recovery of zinc from one mine waste (MW) originated in an old zinc/lead mine exploitation. Two biochar-Fe composites (BM-Fe and HM-Fe) were used as catalysts in the leaching of zinc and copper. Biochars were obtained by pyrolysis of pruning waste (BM-Fe) or hydrochar from pruning waste (HM-Fe), impregnated with $5 \mathrm{wt} \%$ ferric sulfate. The use of the two biochars did not improve the amount of zinc recovered, but was able to reduce, significantly, the arsenic leaching, promoting its immobilization in the final residue.
\end{abstract}

\section{Graphical Abstract}

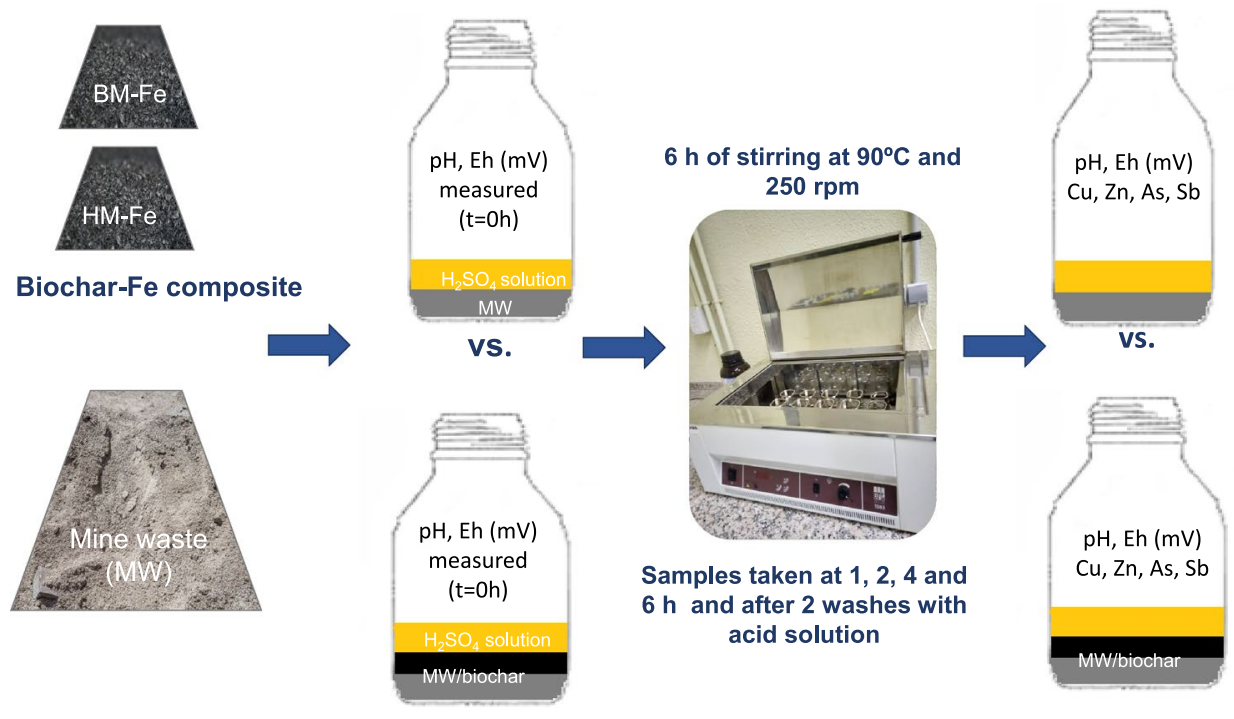

Keywords Hydrometallurgy $\cdot$ Mining waste $\cdot$ Activated carbon $\cdot$ Charcoal $\cdot$ Biochar

\section{Statement of Novelty}

The contributing editor for this article was Grace Ofori-Sarpong.

A. Méndez

anamaria.mendez@upm.es

Extended author information available on the last page of the article
This study investigates the feasibility of metal recovery from mine tailings using a hydrometallurgical process with the addition of biochar-Fe composites. Optimization of experimental conditions can improve the recovery of zinc 
and copper while minimizing arsenic mobility. The use of biochar-Fe composites reduced arsenic leaching, promoting its immobilization in the final residue. In addition, leaching of mine waste in the presence of biochar-Fe composite led to residues with phytostimulation properties, contributing to reduce their environmental impact.

\section{Introduction}

Mining and processing of mineral resources for metals production generate large amounts of waste. Initially, these wastes were discharged into the environment, in the absence of any previous treatment, but, in recent years, these wastes have been deposited in controlled tailings dams. However, failures in tailings dam storage have originated not only several environmental problems [1], but also multiple human risks. One of the most famous accidents in Europe was the spill of large-scale sulfide tailings dam in Los Frailes (Aznalcóllar, Spain). It caused the inundation of the floodplains of the rivers Agrio and Guadiamar [2,3]. Furthermore, the tailings flood was on the verge to affect the Guadalquivir marshlands, threatening the Doñana Natural and National Parks' ecosystems. In order to prevent similar issues in the future, there is a great need to perform new economically feasible ways of mining waste management that not only favor the valorisation of available resources, but also, to perform a safe environmental remediation recovering lands for other uses. According to article 5 of the Directive 2006/21/EC related to Extractive Waste (EWD), the management plan shall have the objective of (a) the prevention or reduction of extractive waste generation and of its harmfulness; $(b)$ the recovery of extractive waste by means of recycling, re-using, or reclaiming such waste; and (c) ensuring the short- and long-term safety of the extractive waste, in particular by considering as part of the design [4].

Some extractive mine wastes still contain valuable and/or critical metals and their recovery is one of the most effective techniques to prevent metals pollution, achieving an economic advantage [5-8]. However, in most cases, the low concentration of valuable metals hinders their economic benefit. It is well known that hydrometallurgy is one of the most efficient technologies to recover valuable metals from low-grade ores and wastes, being sulfuric acid the most often used leaching system due to low price, availability, and dissolution capacity [9-11]. However, some mining wastes related to the exploitation of metallic deposits like copper, zinc, or lead are rich in sulfide minerals and show low solubility in sulfuric medium [12]. Recently, different researchers indicated that some carbon materials such as black carbon or activated carbon improved the kinetics of leaching of sulfide minerals such as chalcopyrite $[13,14]$ or enargite $[15,16]$. The presence of carbon materials in the adequate ratio [14] leads to a substantial increase in copper extraction rate, probably due to the decreases in the redox potential, as well as galvanic interaction between sulfide particles and the carbon material surface [17, 18].

Old mine wastes, depending on the geological context of metal deposits, contain significant residual sulfide and sulfosalt content, with different reactivity under atmospheric conditions that are responsible for generating contamination. Previous works performed by our research group have shown that activated carbon and charcoal addition can also increase the extraction of $\mathrm{Zn}$ and $\mathrm{Cu}$ from mine tailings. In spite of the different properties between activated carbon and charcoal, their effect in the leaching of $\mathrm{Zn}$ and $\mathrm{Cu}$ was similar [19]. This result can open the prospect to use low-cost carbon materials, like biochar, as catalysts for the leaching of metals and the development of new hydrometallurgical processes. In addition, utilization of biomass, particularly biomass waste, to produce biochar can result in a change to a more circular economy. The potential use of carbon materials as catalysts in the leaching of low-grade ores or old mine tailing with altered minerals could have several advantages. For example, the great stability of carbon materials facilitates its recovery in the process and re-utilization, in a similar way to the use of activated carbon in gold metallurgy [20]. On the other hand, the presence of carbon materials, like biochars, in the final waste could limit their toxicity and environmental impact [21]. Currently, studies focused on the use of carbon materials during leaching processes for metals recovery from mining wastes are insufficient. For this reason, the aim of this work is to study the addition of two biochar-Fe composites in the leaching of zinc and copper from a mining waste. The arsenic concentration in the leaching systems was also analyzed. Finally, a phytotoxicity test was performed on the final residue obtained after leaching experiments.

\section{Materials and Methods}

\section{Materials Selection and Characterization}

One mining waste sample (MW) was selected from one abandoned mining deposit located in the southeast of Spain. The origin of MW was an abandoned zinc/lead ore extraction mine. Sample was air-dried, crushed, and sieved under $50 \mu \mathrm{m}$, using a ceramic mill. Wavelength X-ray fluorescence (WDXRF) was achieved in an ARL ADVANT'XP+ sequential model from THERMO (SCAI-Malaga University) and metal composition was obtained by an UNIQUANT Integrated Software. A Bruker diffractometer, model D8 Advance A25 (SCAI-Malaga University), was used for X-ray Diffraction (XRD) analysis. 
Two biochar-Fe composites obtained by pyrolysis of pruning waste impregnated with $5 \mathrm{wt} \%$ ferric sulfate $(\mathrm{BM}-\mathrm{Fe})$ or pyrolysis of hydrochar from pruning waste impregnated with $5 \mathrm{wt} \%$ ferric sulfate (HM-Fe) were used. Ingelia (Náquera, Spain) supplied pruning waste and hydrochar from pruning waste. The two types of biochar-Fe composites were prepared by impregnation with ferric sulfate salt of biomass waste or corresponding hydrochar, followed by pyrolysis at $500{ }^{\circ} \mathrm{C}$ for $5 \mathrm{~h}$ as was described in detail by Álvarez et al. [22].

The two biochar-Fe composites were air-dried, crushed, and sieved below $100 \mu \mathrm{m}$ using a ceramic mill. Characterization of samples was performed according to the following properties: $\mathrm{pH}$ and redox potential (Eh) were determined with a biochar/distilled water ratio of $0.1 / 25\left(\mathrm{~g} \mathrm{~mL}^{-1}\right)$, using a Crison micro pH 2000 and Eh in a pH 60 DHS, respectively. Elemental analysis $(\mathrm{C}, \mathrm{H}, \mathrm{N}, \mathrm{O}$ and $\mathrm{S}$ in \%) was performed using a LECO CHNS 932 Analyser by dry combustion. Ash content (\%) was calculated by combustion of samples at $850{ }^{\circ} \mathrm{C}$ in a Labsys Setaram TGA analyzer. Twenty $\mathrm{mg}$ of each sample was heated at a rate of $15^{\circ} \mathrm{C} / \mathrm{min}$ up to $850{ }^{\circ} \mathrm{C}$ using $30 \mathrm{~mL} \mathrm{~min}^{-1}$ of air. Oxygen was obtained by difference as $100 \%-(\% \mathrm{C}+\% \mathrm{H}+\% \mathrm{~N}+\% \mathrm{~S}+\%$ Ash $)$. Following that, $\mathrm{O} / \mathrm{C}$ and $\mathrm{H} / \mathrm{C}$ ratios were calculated from the elemental analysis results. Porosity (\%) was determined by $\mathrm{Hg}$ porosimetry, which was carried out using a Micromeritics AutoPore IV 9500 equipment. BET surface area $\left(S_{\mathrm{BET}}\right)$, was analyzed by nitrogen adsorption isotherm, which was carried out at $77 \mathrm{~K}$ in a Micromeritics Tristar 3.00.

\section{Leaching Experiments}

Leaching experiments were performed using a thermostatic bath with stirring model GFL 1083 (heating power of $1500 \mathrm{~W}$ and the voltage $230 \mathrm{~V}$ ). The temperature conditions and stirring speed were $90{ }^{\circ} \mathrm{C}$ and $250 \mathrm{rpm}$, respectively. Approximately, $2.5 \mathrm{~g}$ of MW were weighed in a $250 \mathrm{~mL}$ borosilicate glass jar. Then, $50 \mathrm{~mL}$ of leaching agents $\left(\mathrm{H}_{2} \mathrm{SO}_{4} 0.25 \mathrm{M}\right.$ or $0.17 \mathrm{M}$ solutions with $\mathrm{pH}$ value of 0.6 and 1.0 respectively). Sulfuric acid with $95-98 \%$ purity was supplied by Sigma-Aldrich. Except for the control samples, each carbon material was added to MW in a $1 / 0.5$ or $1 / 0.25$ ratio $(w / w)$.

One $\mathrm{mL}$ of each sample of the supernatant liquor was withdrawn at different reaction times $(1,2,4$ and $6 \mathrm{~h})$. The sampling procedure was as follows: Firstly, in order to let the sample settle and favor the decantation of solids, the stirring was stopped. After that, $1 \mathrm{~mL}$ of the supernatant solution was removed, filtered, and transferred to a $25 \mathrm{~mL}$ graduated flask, making up to volume with distilled water. In order to compensate the extracted leaching solution and maintain the same conditions throughout the system, $1 \mathrm{~mL}$ of the corresponding sulfuric acid solution was added. After $6 \mathrm{~h}$ of leaching, the stirring was stopped, and the supernatant was allowed to cool down. After that, the pulp was filtered and the solid was washed twice with $50 \mathrm{~mL}$ of $\mathrm{H}_{2} \mathrm{SO}_{4}$ solution of $\mathrm{pH}$ 2. $\mathrm{pH}$ and $\mathrm{Eh}$ of leaching solution were determined along leaching experiments using a Crison micro pH 2000 and a pH 60 DHS, respectively.

$\mathrm{Zn}, \mathrm{Cu}, \mathrm{As}$, and $\mathrm{Sb}$ concentration in the leaching and washed solutions were determined using an inductively coupled plasma mass spectrometry, model ICP-MS Elan DRCe (SCIEX Perkin Elmer) from SCAI-Malaga University.

\section{Phytotoxicity of Residue After Leaching Experiments}

The potential phytotoxicity of the final residue generated after leaching experiments was determined using the germination test described by Zucconi et al. [23]. Briefly, five seeds of Lepidium sativum were placed on petri dishes with filter papers at the bottom, then $5 \mathrm{~mL}$ of aqueous extract $(1 / 10 \mathrm{w} / \mathrm{v})$ of each sample was added. Seeds were maintained in the dark at $28{ }^{\circ} \mathrm{C}$. Germination percentages $(G)$ with respect to control (distilled water) and root lengths were determined after $48 \mathrm{~h}$. The germination index (GI) was estimated as $\mathrm{GI}=G \cdot \mathrm{Le} / \mathrm{Lc}$ where $G$ is the percentage of germinated seeds in each extract with respect to the control, Le is the mean total root length of the germinated seeds in each extract, and Lc is the average root length of the control.

\section{Statistical Analysis}

The significance of the differences among means was assessed by analysis of variance (ANOVA), using the Tukey test as a post hoc. Every analysis was performed in triplicate $(n=3)$.

\section{Results and Discussion}

\section{Characteristics of Samples}

Analysis by Rietveld method of XRD (Fig. 1) shows that main crystalline mineral species present in MW sample were the following: muscovite (49.6\%), followed by quartz $(38.9 \%)$, corkite $(6.9 \%)$, and calcite magnesium $(3.5 \%)$ The content of litharge stannite and calcite was lower than $1 \%$. Table 1 summarizes chemical composition of MW, the background ranges, and generic reference levels of some trace elements in the natural soils of the Region of Murcia (Spain) [24]. Background levels are defined as the natural content of metals in a soil from a determined area without any anthropogenic influence. On the other hand, generic reference levels indicate the concentration of metals in the soil which do not pose a greater risk than the maximum 
Fig. 1 XRD pattern of MW sample

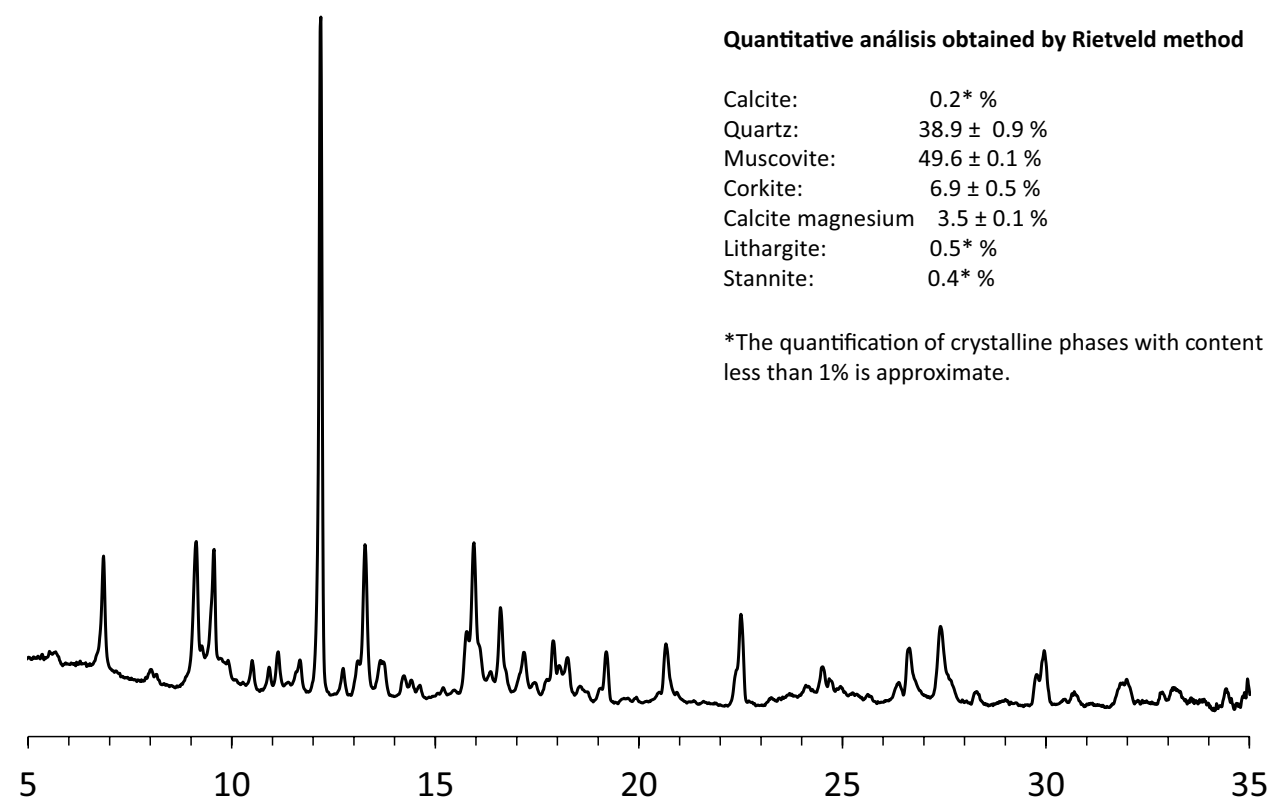

Table 1 Chemical composition of MW sample compared to ranges of some trace elements in soils of the Region of Murcia compared to the abnormal values from the mine wastes of the Sierra Minera [24]

\begin{tabular}{llll}
\hline Element & MW $\left(\mathrm{mg} \mathrm{kg}^{-1}\right)$ & $\begin{array}{l}\text { Background } \\
\text { levels }\left(\mathrm{mg} \mathrm{kg}^{-1}\right)\end{array}$ & $\begin{array}{l}\text { Generic } \\
\text { reference levels } \\
\left(\mathrm{mg} \mathrm{kg}^{-1}\right)\end{array}$ \\
\hline $\mathrm{Fe}$ & 90,700 & - & - \\
$\mathrm{S}$ & 19,400 & - & - \\
$\mathrm{Zn}$ & 13,800 & $16-55$ & $43-92$ \\
$\mathrm{As}$ & 1510 & $5-8$ & $8-12$ \\
$\mathrm{Cu}$ & 435 & $12-23$ & $43-92$ \\
$\mathrm{Sb}$ & 156 & $0.5-1.6$ & $2-3$ \\
$\mathrm{Co}$ & 79 & $5-9$ & $10-13$ \\
\hline
\end{tabular}

acceptable to human health or ecosystems. According to that, each country or region determines the regulatory standards over which a soil can be considered contaminated for different land uses, such as agricultural, industrial, and urban. Although contents of $\mathrm{Cu}(0.0435 \% \pm 0.0022)$, As $(0.151 \% \pm 0.0075)$, Co $(0.0079 \% \pm 0.0007), \mathrm{Zn}$ $(1.38 \% \pm 0.05)$, and $\mathrm{Pb}(2.18 \% \pm 0.07)$ of MW were lower than exploitable concentrations in ores, MW would can be classified as a contaminated soil as the concentration of $\mathrm{Zn}$, $\mathrm{As}, \mathrm{Cu}, \mathrm{Co}$, and $\mathrm{Sb}$ exceeded the background and generic reference levels. These metals are listed as very toxic trace elements due to their high degree of mobilization in soils, and the US Environmental Protection Agency [25] registers most of them as priority pollutants.

Table 2 shows the main properties of two biochar-Fe composites used in this work. HM-Fe showed high $\mathrm{C}$ content than BM-Fe. The lowest $H / C$ ratios and, consequently, the highest aromaticity corresponded to BM-Fe (0.17), whereas $\mathrm{HM}-\mathrm{Fe}$ showed the highest content of oxygen functional groups. The highest surface area corresponded to $\mathrm{HM}-\mathrm{Fe}$ and the lowest to BW-Fe. Finally, two samples show basic $\mathrm{pH}$ and low $\mathrm{Eh}(\mathrm{mV})$ values.

\section{Percentage of Metals Recovery}

Figure 2a provides the recovery of $\mathrm{Zn}(\%)$ from MW treated with sulfuric solutions at $\mathrm{pH} 0.6$ and 1.0, after $6 \mathrm{~h}$ of leaching experiments. Leaching experiments were performed at $90{ }^{\circ} \mathrm{C}$ in order to increase the kinetic of the reactions [9]. The percentage of total $\mathrm{Zn}$ recovered is higher in sulfuric solutions with $\mathrm{pH} 0.6$ (varying from 72.8 to $76.3 \%$ ) than in solution with $\mathrm{pH}$ of 1.0 (ranging from 63.5 to $70.7 \%$ ). In

Table 2 Main characteristics of biochar-Fe composites

\begin{tabular}{|c|c|c|c|c|c|c|c|c|c|c|c|}
\hline Sample & $\mathrm{C}(\%)$ & $\mathrm{H}(\%)$ & $\mathrm{O}(\%)$ & $\mathrm{H} / \mathrm{C}$ & $\mathrm{O} / \mathrm{C}$ & Ash (wt\%) & $\mathrm{pH}$ & $\mathrm{Eh}(\mathrm{mV})$ & $S_{\mathrm{BET}}\left(\mathrm{m}^{2} / \mathrm{g}\right)$ & $\begin{array}{l}\text { Micro area } \\
\left(\mathrm{m}^{2} \mathrm{~g}^{-1}\right)\end{array}$ & Porosity (\%) \\
\hline $\mathrm{BM}-\mathrm{Fe}$ & 20.18 & 0.29 & 0.71 & 0.17 & 0.03 & 70.38 & 7.33 & 314 & 56 & 55 & 72.2 \\
\hline $\mathrm{HM}-\mathrm{Fe}$ & 43.81 & 0.81 & 8.14 & 0.22 & 0.14 & 40.98 & 8.22 & 298 & 183 & 183 & 80.4 \\
\hline
\end{tabular}



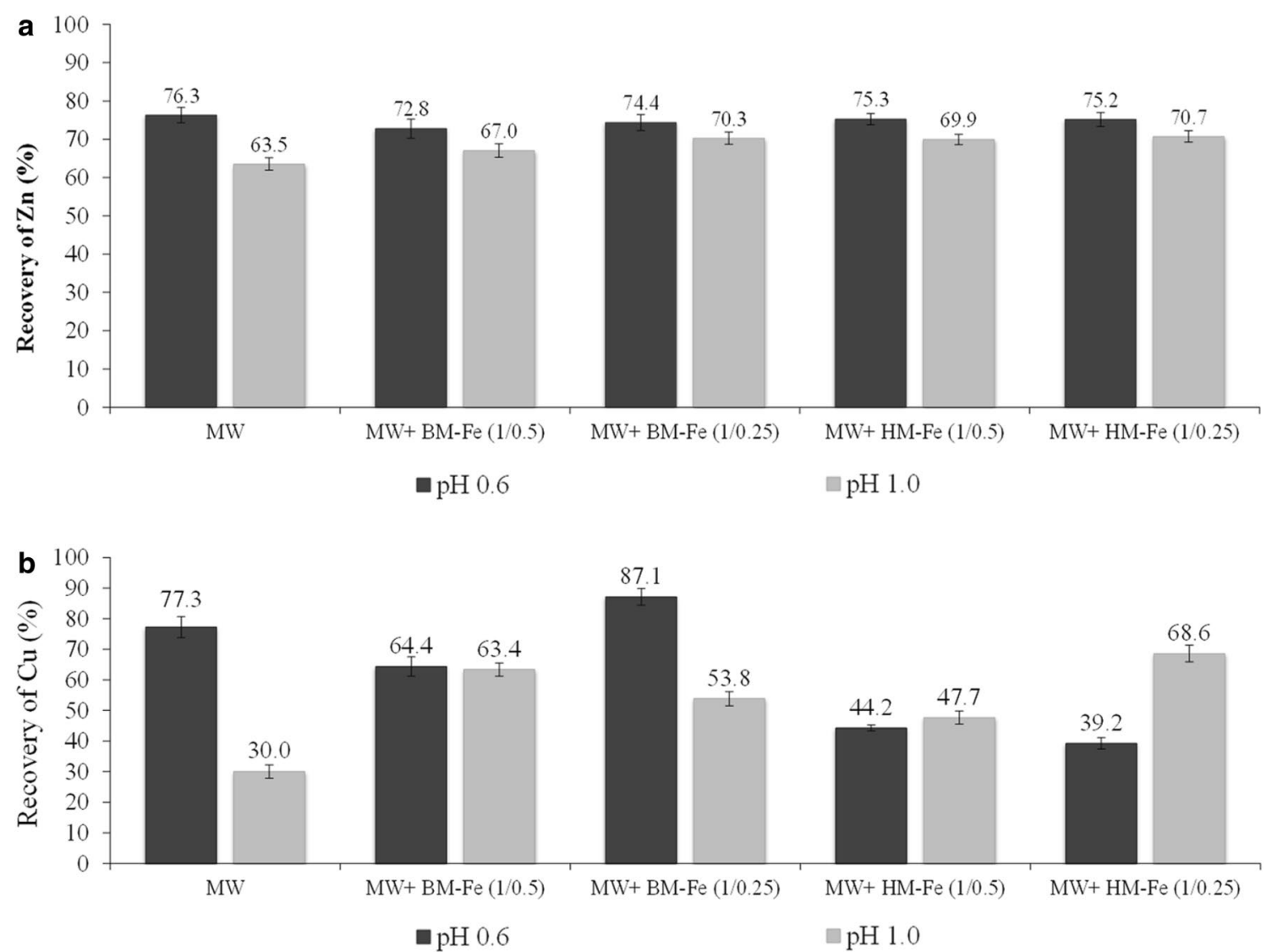

Fig. 2 Recovery of $\mathrm{Zn}(\mathbf{a})$ and $\mathrm{Cu}(\mathbf{b})$

general, the addition of biochar-Fe composites increased the total $\mathrm{Zn}$ recovered at $\mathrm{pH} 1.0$, whereas at $\mathrm{pH} 0.6$, the addition of biochar-Fe composites slightly diminished the amount of $\mathrm{Zn}$ recovered.

The addition of BM-Fe with ratio 1/0.25 and using the leaching solution at $\mathrm{pH} 0.6$, significantly increased the recovery of $\mathrm{Cu}$ (Fig. 2b). In a similar way to the recovery of $\mathrm{Zn}$, using sulfuric leaching solution at $\mathrm{pH} 1$, the addition of both biochar-Fe composites increased the recovered of $\mathrm{Cu}$ with respect to control.

With respect to As (Fig. 3a), the highest leaching was obtained at low $\mathrm{pH}(0.6)$. It is important to highlight that the addition of BM-Fe and HM-Fe biochars significantly reduced the leaching of As. During carbon-catalyzed atmospheric leaching of enargite, Jahromi et al. [26] concluded that the presence of activated carbon with high ferric concentration can immobilize As, which precipitates as scorodite particles. In our research, leaching was performed without ferric acid addition. However, biochars were prepared with $\mathrm{Fe}$ in their composition leading to higher As immobilization in the final residue. Previous works have proven that Fe-impregnated biochar has considerable ability for As immobilization in contaminated soils, decreasing the available As and increasing the As bound to Fe oxides of biochars [27]. The decrease in the leaching of As was an important improvement in the recovery of metals from mining wastes or minerals as As could be immobilized in the residue, decreasing costs of leaching solution purification. The behavior of $\mathrm{Sb}$ was similar to that of As, decreasing the amount of Sb leached with the addition of BM-Fe and HM-Fe (Fig. 3b). Carbon structure and the presence of Fe oxides in their surface can improve their $\mathrm{Sb}$ adsorption capacity [28-30]. As Tighe et al. [31] indicated, similarly to As, Sb can be immobilized in the residue due to their strong affinity to non-crystalline $\mathrm{Al}$ and Fe hydroxides.

\section{Evolution of $\mathrm{Zn}, \mathrm{Cu}$, and As Extraction During Leaching Experiments}

The evolution of $\mathrm{Zn}, \mathrm{Cu}$, and As concentration in the leaching solution is represented in Figs. 4, 5, and 6, respectively. A similar trend over time was observed for three elements. $\mathrm{Cu}, \mathrm{Zn}$, and As rise steadily between 1 

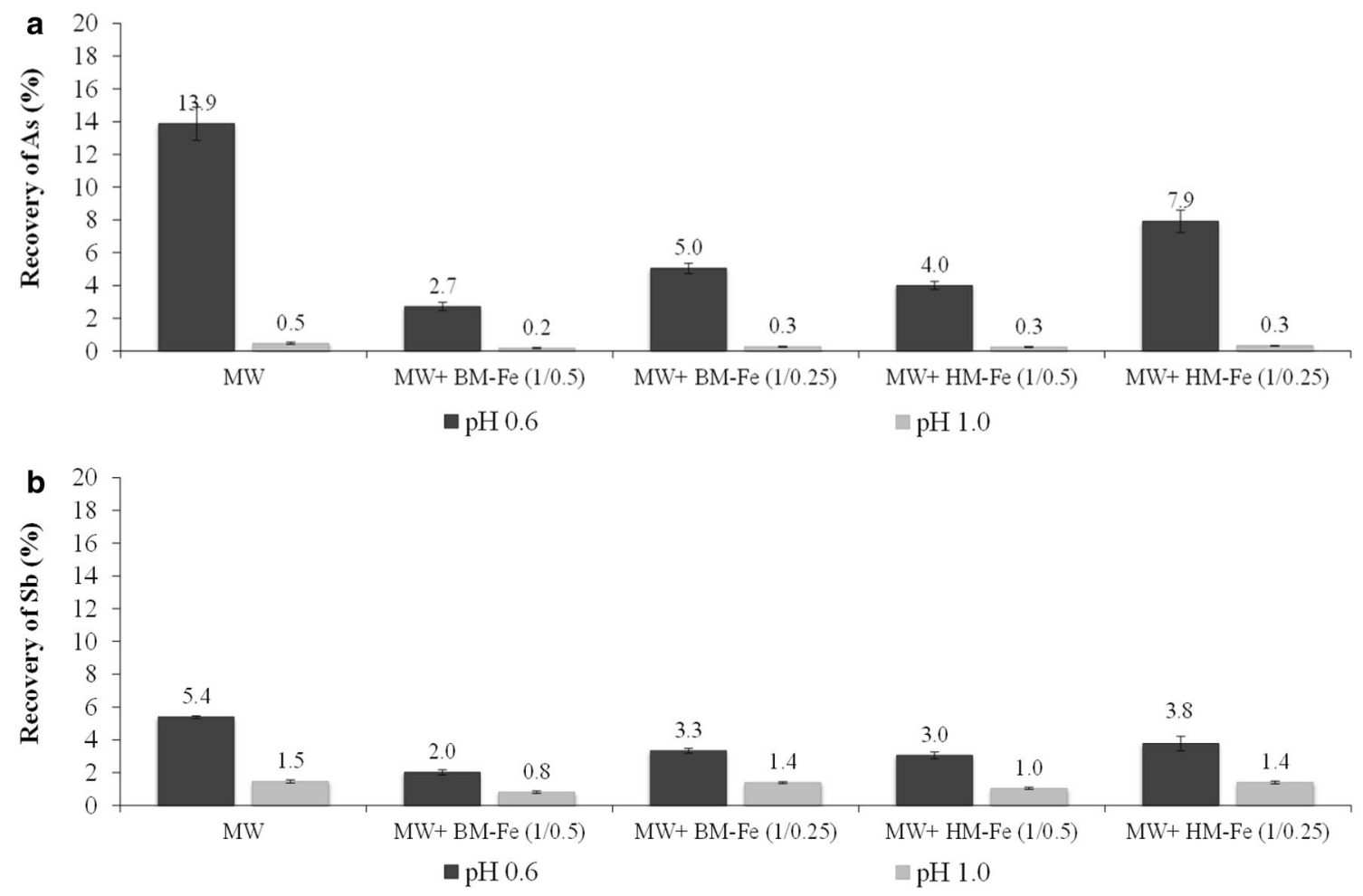

Fig. 3 Recovery of As (a) and $\mathrm{Sb}(\mathbf{b})$

a

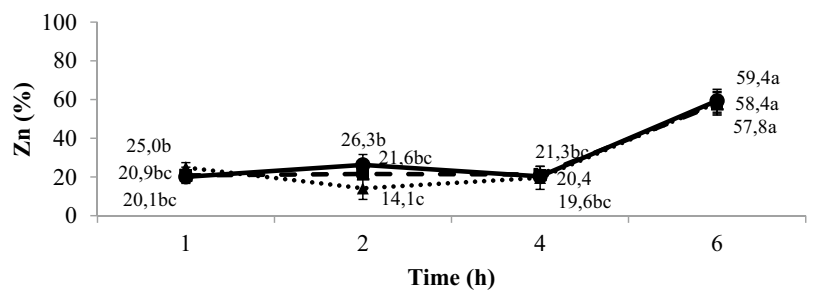

$\rightarrow$ MW $\quad \cdots . . . M W / B M-F e ~ 1 / 0.5$

C

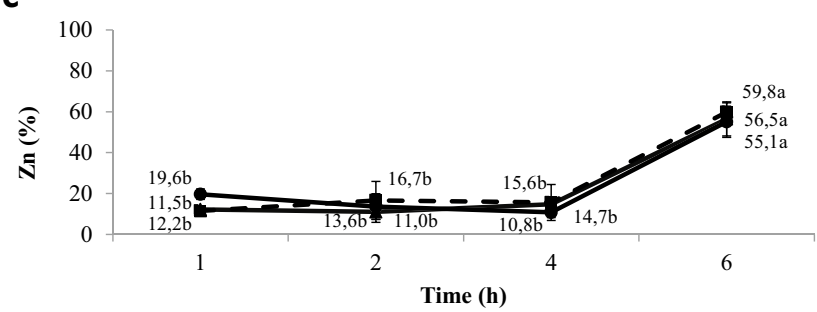

$\rightarrow$ MW $\rightarrow$ MW/BM-Fe $1 / 0.5 \quad-$ - MW/BM-Fe $1 / 0.25$ b

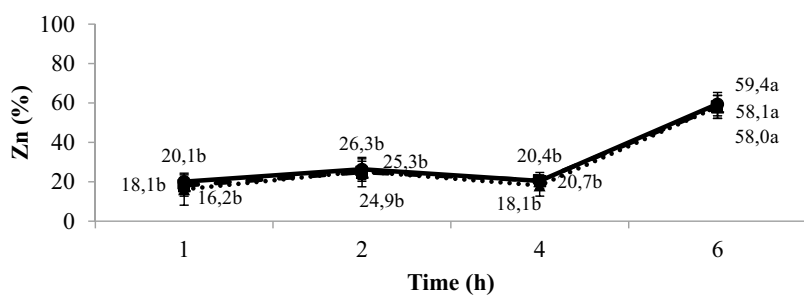

$\longrightarrow$ MW $\quad$..... MW/HM-Fe $1 / 0.5$

- MW/HM-Fe 1/0.25

d

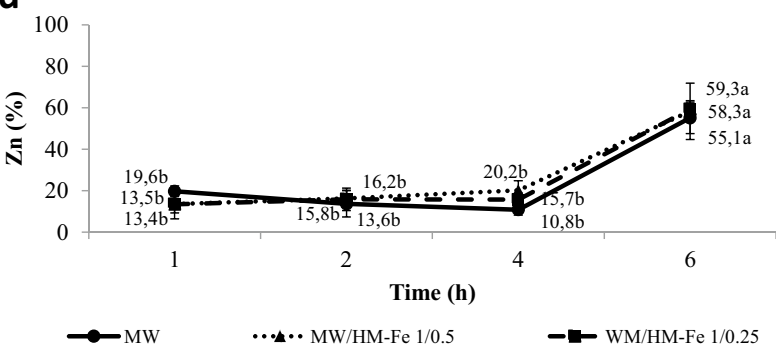

Fig. 4 Extraction of $\mathrm{Zn}(\%)$ in the leaching solution at $\mathrm{pH} 0.6(\mathbf{a}, \mathbf{b})$ and $\mathrm{pH} 1.0(\mathbf{c}, \mathbf{d})$ 


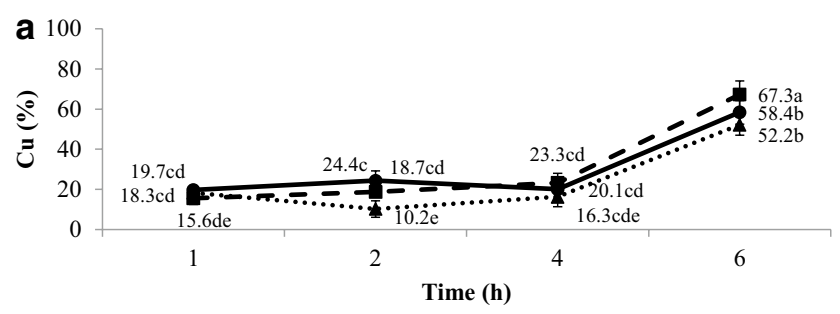

$\longrightarrow$ MW $\quad \cdots \wedge . \cdot$ MW + BM-Fe (1/0.5) $\quad-$ MW + BM-Fe (1/0.25)

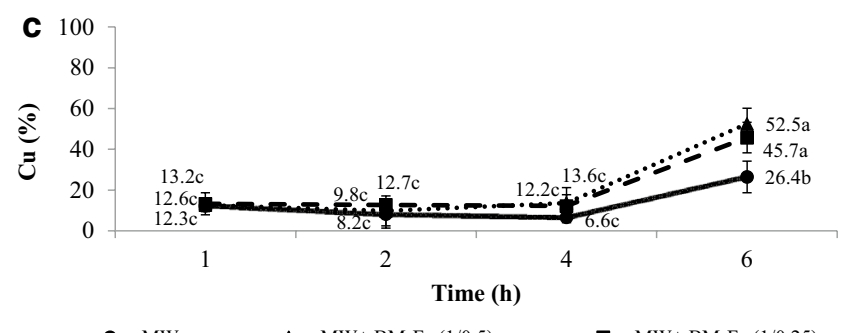

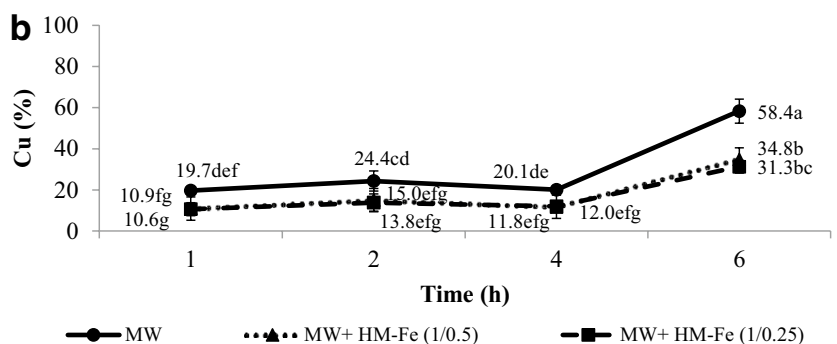

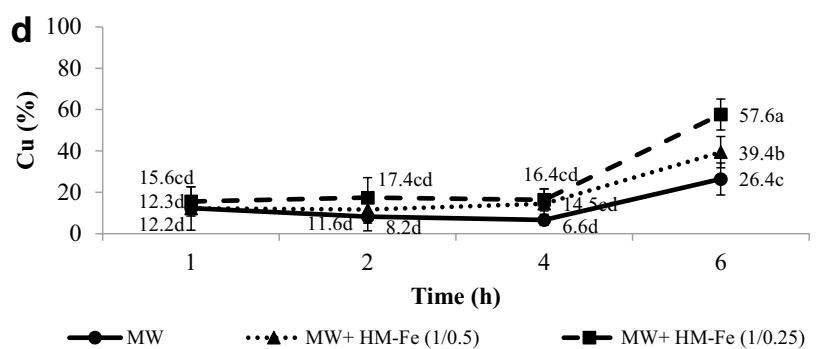

Fig. 5 Extraction of $\mathrm{Cu}(\%)$ in the leaching solution at $\mathrm{pH} 0.6(\mathbf{a}, \mathbf{b})$ and $\mathrm{pH} 1.0(\mathbf{c}, \mathbf{d})$
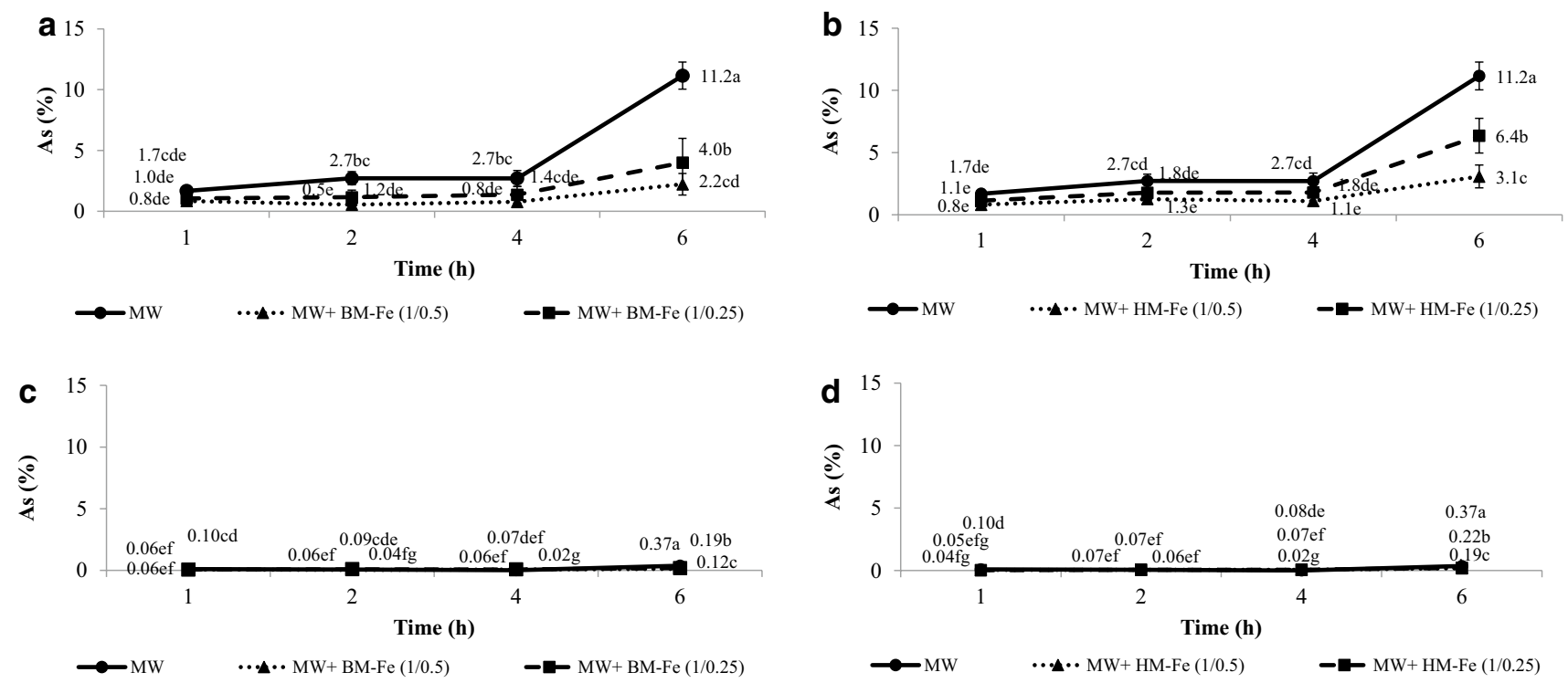

Fig. 6 Extraction of As (\%) in the leaching solution at pH $0.6(\mathbf{a}, \mathbf{b})$ and $\mathrm{pH} 1.0(\mathbf{c}, \mathbf{d})$

and $4 \mathrm{~h}$ of leaching, increasing significantly between 4 and $6 \mathrm{~h}$.

\section{Eh and pH Evolution During Leaching Experiments}

Figure 7 shows the Eh evolution during leaching of $\mathrm{MW}$ and $\mathrm{MW}$ treated with $\mathrm{BM}-\mathrm{Fe}$ and $\mathrm{HM}-\mathrm{Fe}_{2} \mathrm{SO}_{4}$ solution with pH 0.6 (Fig. 6a) and pH 1.0 (Fig. 6b). In general, the addition of biochars decreased the Eh of leaching systems. This result was similar to previous results obtained by Álvarez et al. [19]. Other researches have observed Eh reduction after carbon black addition to chalcopyrite in the sulfuric acid leaching system [17]. Galvanic interactions may occur between carbon structures and minerals in the acidic medium, which may decrease the Eh of the system [32]. It is expected that the addition of carbon materials lead to a decrease in Eh due to their $\mathrm{C}$ content and, consequently, low Eh values (Table 1). At $\mathrm{pH} 0.6$, the main reductions in the Eh corresponded to samples MW/BM-Fe and MW/HM-Fe with ratio 1/0.5. However, at $\mathrm{pH} 1.0$, the Eh was similar using ratios $1 / 0.5$ and $1 / 0.25$. 

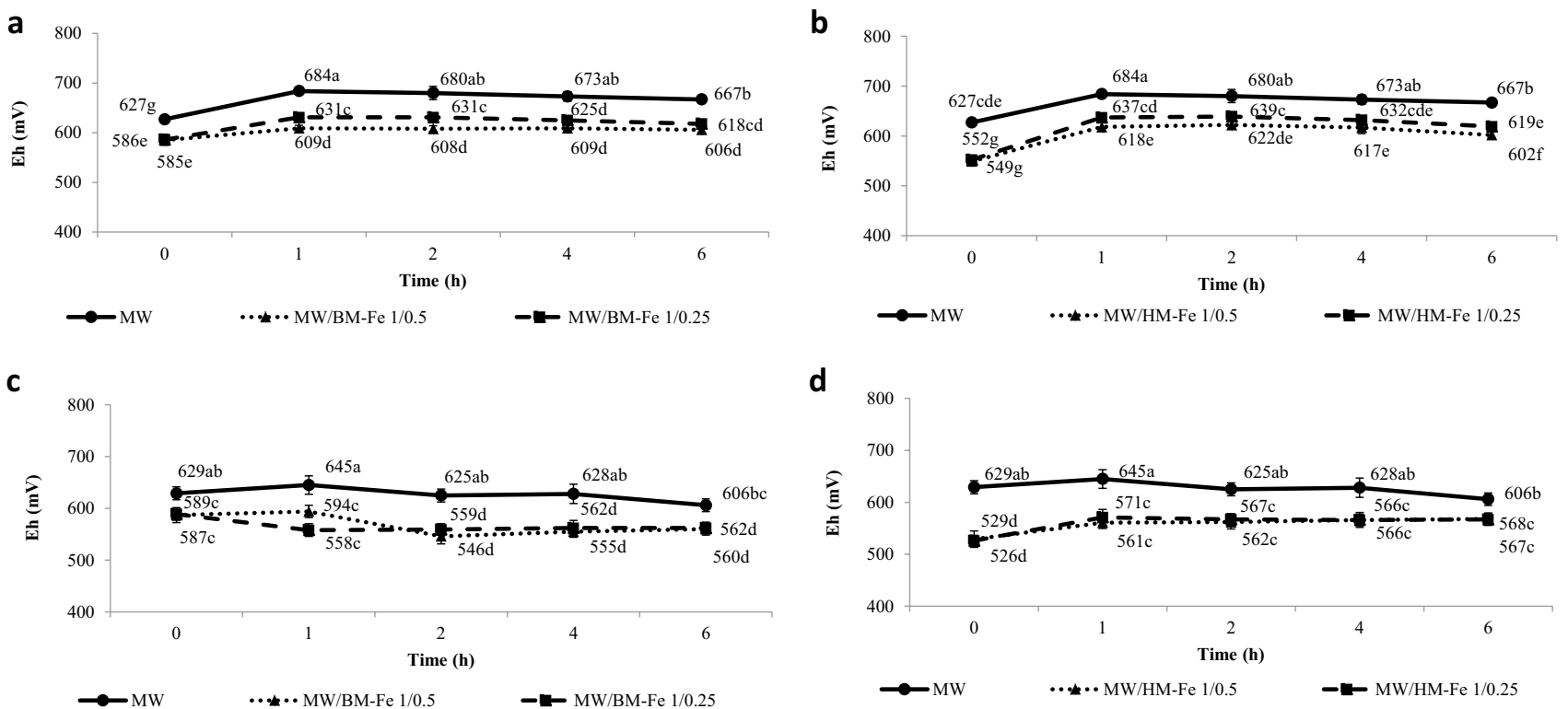

Fig. 7 Eh (mV) evolution of samples in leaching solutions with $\mathrm{pH} 0.6(\mathbf{a}, \mathbf{b})$ and $\mathrm{pH} 1.0(\mathbf{c}, \mathbf{d})$

Figure 8 provides the $\mathrm{pH}$ evolution during leaching of MW and MW treated with BM-Fe and $\mathrm{HM}-\mathrm{Fe}$ in $\mathrm{H}_{2} \mathrm{SO}_{4}$ solution with an initial $\mathrm{pH}$ of 0.6 (Fig. $7 \mathrm{a}$ and $\mathrm{b}$ ) and with a pH of 1.0 (Fig. 7c and d). In general, the $\mathrm{pH}$ of the leaching systems increased with time (from 0 to $6 \mathrm{~h}$ ). However, it is important to note that when leaching is performed in the presence of biochar-Fe composites and, especially with more concentrated $\mathrm{H}_{2} \mathrm{SO}_{4}$ solution, the $\mathrm{pH}$ increment was lower than without biochar addition (Fig. 8a and b). This result can be due to the modification of biochar surface with leaching agent and the generation of acidic groups on their surface, with a low acid consumption during leaching process. Álvarez et al. [18] observed that the addition of carbon materials significantly decreased the $\mathrm{pH}$ of the ferric acid solution $\left(\mathrm{Fe}^{3+/} \mathrm{H}_{2} \mathrm{SO}_{4} 0.5 \mathrm{M}\right)$.

\section{Phytotoxicity of Residue Produced After Leaching Process}

Table 3 shows the germination index of residues obtained after leaching and washing of MW and MW treated with $\mathrm{BM}-\mathrm{Fe}$ and $\mathrm{HM}-\mathrm{Fe}$. In order to compare, the germination index of original MW sample before leaching was also determined (MW control). According to Emino and Warman [33], samples with GI $>100 \%$ can be considered phytonutrient or phytostimulant. In this study, the addition of $\mathrm{BM}-\mathrm{Fe}$ increases the GI of final leaching residue from $80 \%$ in the MW control (and $71-77 \%$ in MW after leaching) to values higher than $100 \%$. With the addition of $\mathrm{HM}-\mathrm{Fe}$, the GI of final residues was different depending on the $\mathrm{pH}$ used during the leaching process, being lower after the use of leaching solutions with $\mathrm{pH}$ 0.6.

With respect to electrical conductivity (EC), of the EC of MW significantly decreased after leaching and washing experiments, from $2.95 \mathrm{dSm}^{-1}$ to values ranging from 0.05 to $0.40 \mathrm{dSm}^{-1}$.

Results summarized in Table 3 showed that leaching of mine waste with the addition of BM-Fe in $1 / 0.5$ or $1 / 0.25$ ratios led to residues without phytotoxic characteristics. In fact, in these cases, the final residues showed phytoestimulation properties ( $\mathrm{GI}>100)$ indicating the potential used as growing media for the development of phytoremediation technologies in these mining areas.

\section{Conclusions}

The addition of biochar-Fe composites as catalysts in the leaching of metals from mine wastes could be a promising alternative to traditional hydrometallurgical processes. The use of biochars BM-Fe and HM-Fe did not improve the amount of zinc recovered, but was able to reduce, significantly, the arsenic leaching, promoting its immobilization in the final residue. The addition of biochar BM-Fe in a low ratio (1/0.25), using leaching solution of $\mathrm{pH} 0.6$, increased copper recovery. Leaching of mine waste in the presence of $\mathrm{BM}-\mathrm{Fe}$ generates residues with phytostimulation characteristics. The use of biochar BM-Fe as catalyst in hydrometallurgical processes can open an interesting line of research, as the final residues can be used as growing 

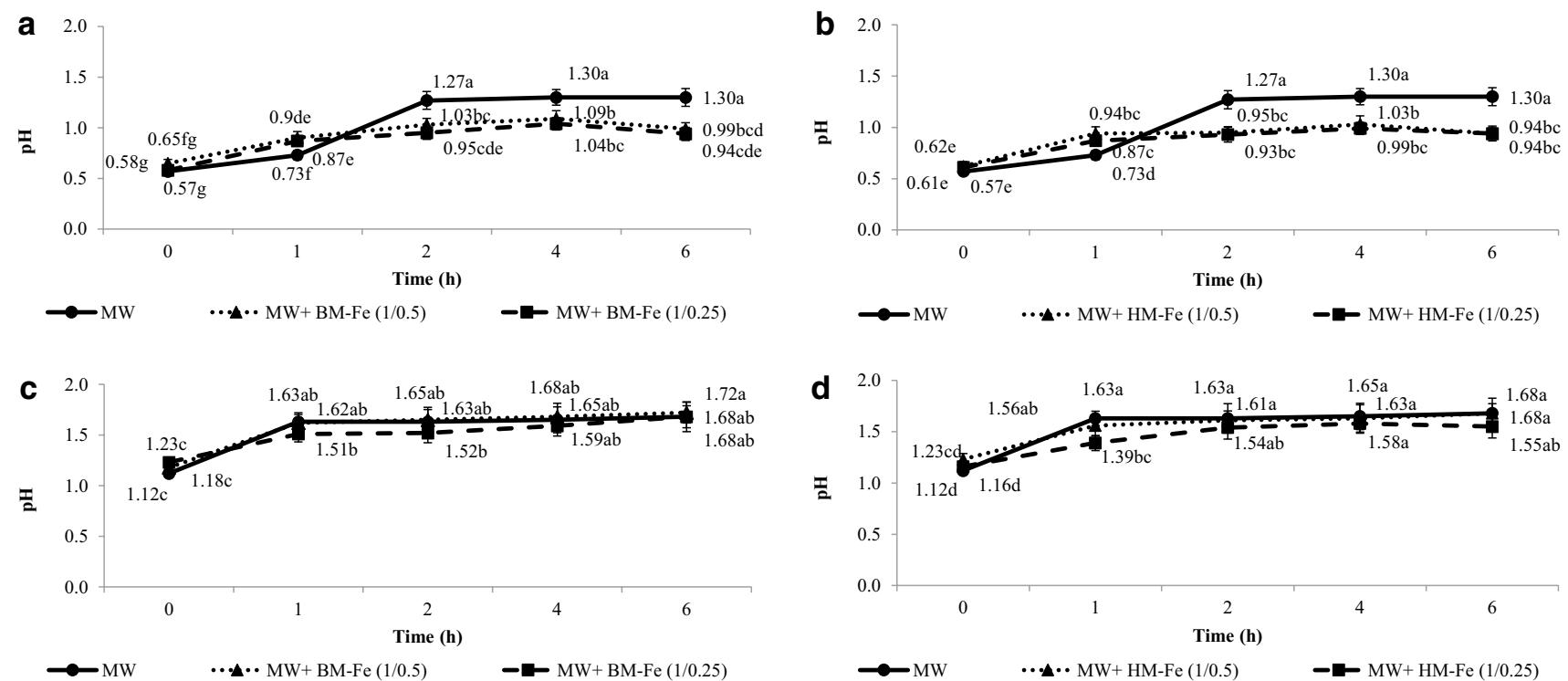

Fig. 8 pH evolution of samples in leaching solutions with $\mathrm{pH} 0.6(\mathbf{a}, \mathbf{b})$ and $\mathrm{pH} 1.0(\mathbf{c}, \mathbf{d})$

Table 3 Germination index (GI), pH, and electrical conductivity (EC) of MW before and after leaching processes

\begin{tabular}{|c|c|c|c|c|c|c|}
\hline Sample & \multicolumn{2}{|c|}{ GI $(\%)$} & \multicolumn{2}{|c|}{$\mathrm{pH}$} & & $\mathrm{EC}\left(\mathrm{dS} \mathrm{m} \mathrm{m}^{-1}\right)$ \\
\hline MW & \multicolumn{2}{|c|}{$80 \pm 6$} & \multicolumn{2}{|c|}{$3.19 \pm 0.05$} & & $2.95 \pm 0.05$ \\
\hline \multirow[t]{2}{*}{ After leaching process } & \multicolumn{3}{|c|}{$\mathrm{H}_{2} \mathrm{SO}_{4} \mathrm{pH} 0.6$} & \multicolumn{3}{|c|}{$\mathrm{H}_{2} \mathrm{SO}_{4} \mathrm{pH} 1.0$} \\
\hline & GI (\%) & $\mathrm{pH}$ & $\mathrm{EC}\left(\mathrm{dS} \mathrm{m} \mathrm{m}^{-1}\right)$ & GI (\%) & $\mathrm{pH}$ & $\mathrm{EC}\left(\mathrm{dS} \mathrm{m}{ }^{-1}\right)$ \\
\hline MW & $71 \pm 6$ & $4.47 \pm 0.12$ & $0.08 \pm 0.02$ & $77 \pm 3$ & $4.13 \pm 0.10$ & $0.08 \pm 0.03$ \\
\hline $\mathrm{MW}+\mathrm{BM}-\mathrm{Fe}(1 / 0.5)$ & $132 \pm 7$ & $3.54 \pm 0.01$ & $0.18 \pm 0.04$ & $111 \pm 6$ & $3.74 \pm 0.01$ & $0.40 \pm 0.02$ \\
\hline $\mathrm{MW}+\mathrm{BM}-\mathrm{Fe}(1 / 0.25)$ & $101 \pm 12$ & $3.63 \pm 0.07$ & $0.11 \pm 0.02$ & $116 \pm 10$ & $3.73 \pm 0.03$ & $0.16 \pm 0.03$ \\
\hline $\mathrm{MW}+\mathrm{HM}-\mathrm{Fe}(1 / 0.5)$ & $80 \pm 3$ & $3.74 \pm 0.02$ & $0.05 \pm 0.02$ & $108 \pm 6$ & $3.83 \pm 0.03$ & $0.16 \pm 0.01$ \\
\hline $\mathrm{MW}+\mathrm{HM}-\mathrm{Fe}(1 / 0.25)$ & $62 \pm 1$ & $3.67 \pm 0.08$ & $0.05 \pm 0.02$ & $88 \pm 8$ & $3.79 \pm 0.02$ & $0.09 \pm 0.02$ \\
\hline
\end{tabular}

media for phytoremediation technologies, reducing their environmental impact. Further research will be necessary to optimize the characteristics of the biochars and their use in the leaching of metals.

Funding Open Access funding provided thanks to the CRUE-CSIC agreement with Springer Nature. This research was funded by Ministerio de Ciencia, Innovación y Universidades (MCIU), Agencia Estatal de Investigación (AEI), and Fondo Europeo de Desarrollo Regional (FEDER) with Grant Number RTI2018-096695-B-C31.

\section{Declarations}

Conflict of interest On behalf of all authors, the corresponding author states that there is no conflict of interest.

Open Access This article is licensed under a Creative Commons Attribution 4.0 International License, which permits use, sharing, adaptation, distribution and reproduction in any medium or format, as long as you give appropriate credit to the original author(s) and the source, provide a link to the Creative Commons licence, and indicate if changes were made. The images or other third party material in this article are included in the article's Creative Commons licence, unless indicated otherwise in a credit line to the material. If material is not included in the article's Creative Commons licence and your intended use is not permitted by statutory regulation or exceeds the permitted use, you will need to obtain permission directly from the copyright holder. To view a copy of this licence, visit http://creativecommons.org/licenses/by/4.0/.

\section{References}

1. Cappuyns V, Alian V, Vassilieva E, Swennen R (2014) pH dependent leaching behavior of $\mathrm{Zn}, \mathrm{Cd}, \mathrm{Pb}, \mathrm{Cu}$ and As from mining wastes and slags: kinetics and mineralogical control. Waste Biomass Valor 5:355-368. https://doi.org/10.1007/ s12649-013-9274-3

2. Rico M, Benito G, Salgueriro A, Diez-Herrero A, Pereira HG (2008) Reported tailings dam failures: a review of the European 
incidents in the worldwide context. J Hazard Mater 152:846-852. https://doi.org/10.1016/j.jhazmat.2007.07.050

3. Rico M, Benito G, Díez-Herrero A (2008) Floods from tailings dam failures. J Hazard Mater 154(1-3):79-87. https://doi.org/10. 1016/j.jhazmat.2007.09.110

4. European Parliament (2006) Directive 2006/21/EC of the European Parliament and of the Council of 15 March 2006 on the management of waste from extractive industries and amending Directive 2004/35/EC - Statement by the European Parliament, the Council and the Commission. OJ L 102, 11.4.2006, pp 15-34

5. Alcalde J, Kelm U, Vergara D (2018) Historical assessment of metal recovery potential from old mine tailings: a study case for porphyry copper tailings, Chile. Miner Eng 127:334-338. https:// doi.org/10.1016/j.mineng.2018.04.022

6. Araya N, Kraslawski A, Cisternas LA (2020) Towards mine tailings valorization: recovery of critical materials from Chilean mine tailings. J Clean Prod 263:121555. https://doi.org/10.1016/j.jclep ro.2020.121555

7. Deng Y, Xu X, Wang R, Zhao Y (2018) Characterization and photocatalytic evaluation of Fe-loaded mesoporous MCM-41 prepared using iron and silicon sources extracted from iron ore tailing. Waste Biomass Valor 11:1491-1498. https://doi.org/10. 1007/s12649-018-0460-1

8. Drif B, Taha Y, Hakkou R, Benzaazoua M (2021) Integrated valorization of silver mine tailings through silver recovery and ceramic materials production. Miner Eng 170:107060. https://doi. org/10.1016/j.mineng.2021.107060

9. Asadi T, Azizi A, Lee JC, Jahani M (2017) Leaching of zinc from a lead-zinc flotation tailing sample using ferric sulphate and sulfuric acid media. J Environ Chem Eng 5(5):4769-4775. https:// doi.org/10.1016/j.jece.2017.09.005

10. Watling HR (2013) Chalcopyrite hydrometallurgy at atmospheric pressure: 1 . Review of acidic sulfate, sulfate-chloride and sulfatenitrate process options. Hydrometallurgy 140:163-180. https:// doi.org/10.1016/j.hydromet.2013.09.013

11. Fleming CA, Brown JA, Botha M (2010) An economic and environmental case for re-processing gold tailings in South Africa. In: Proceedings 2010, 42nd Annual Meeting of the Canadian Mineral Processors. January 2010, pp 365-388

12. Cortés S, Soto EE, Ordóñez JI (2020) Recovery of copper from leached tailing solutions by biosorption. Minerals 10(2):158. https://doi.org/10.3390/min10020158

13. Nakazawa H, Nakamura S, Odashima S, Hareyama W (2016) Effect of carbon black to facilitate galvanic leaching of copper from chalcopyrite in the presence of manganese(IV) oxide. Hydrometallurgy 163:69-76. https://doi.org/10.1016/j.hydromet. 2016.03.003

14. Álvarez ML, Fidalgo JM, Gascó G, Méndez A (2021) Hydrometalurgical recovery of $\mathrm{Cu}$ and $\mathrm{Zn}$ from a complex sulfide mineral by $\mathrm{Fe}^{3+} / \mathrm{H}_{2} \mathrm{SO}_{4}$ leaching in the presence of carbon-based materials. Metals 11(2):286. https://doi.org/10.3390/met11020286

15. Nakazawa H, Koshiya S, Kobayashi H, Matsuhashi T (2017) The effect of carbon black on the oxidative leaching of enargite by manganese(IV) dioxide in sulfuric acid media. Hydrometallurgy 171:165-171. https://doi.org/10.1016/j.hydromet.2016.03.003

16. Jahromi FG, Alvial-Hein G, Cowan DH, Ghahreman A (2019) The kinetics of enargite dissolution in chloride media in the presence of activated carbon and AF5 catalysts. Miner Eng 143:106013. https://doi.org/10.1016/j.mineng.2019.106013

17. Nakazawa H (2018) Effect of carbon black on chalcopyrite leaching in sulfuric acid media at $50^{\circ} \mathrm{C}$. Hydrometallurgy $177: 100$ 108. https://doi.org/10.1016/j.hydromet.2018.03.001

18. Olvera OG, Dixon DG, Asselin E (2013) Electrochemical study of the dissolution of enargite $\left(\mathrm{Cu}_{3} \mathrm{AsS}_{4}\right)$ in contact with activated carbon. Electrochim Acta 107:525-536. https://doi.org/10.1016/j. electacta.2013.06.029

19. Álvarez ML, Méndez A, Rodríguez-Pacheco R, Paz-Ferreiro J, Gascó G (2021) Recovery of zinc and copper from mine tailings by acid leaching solutions combined with carbon-based materials. Appl Sci. https://doi.org/10.3390/app11115166

20. Medina D, Anderson KG (2020) A review of the cyanidation treatment of copper-gold ores and concentrates. Metals 10:897. https://doi.org/10.3390/met10070897

21. Guo X-X, Liu H-T, Zhang J (2020) The role of biochar in organic waste composting and soil improvement: a review. Waste Manage 102:884-889. https://doi.org/10.1016/j.wasman.2019.12.003

22. Álvarez ML, Gascó G, Palacios T, Paz-Ferreiro J, Méndez A (2020) Fe oxides-biochar composites produced by hydrothermal carbonization and pyrolysis of biomass waste. J Anal Appl Pyrolysis 151:104893. https://doi.org/10.1016/j.jaap.2020.104893

23. Zucconi F, Monaco A, ForteM DM (1985) Phytotoxins during the stabilization of organic matter. In: Gasser JKR (ed) Composting of agricultural and other wastes. Elsevier, London, pp 73-86

24. Martínez-Sánchez MJ, Pérez-Sirvent C (2008) Niveles de fondo y niveles genéricos de referencia de metales pesados en suelos de la Región de Murcia (Murcia, Spain). Universidad de Murcia. Región de Murcia, Consejería de Desarrollo Sostenible y Ordenación del Territorio. Murcia, Spain

25. USEPA (1982) Office of the Federal Registration (OFR). Appendix A to Part 423-126 Priorty pollutants. Fed Reg 47:52309

26. Jahromi FG, Ghahreman A (2018) In-situ oxidative arsenic precipitation as scorodite during carbon catalyzed enargite leaching process. J Hazard Mater 360:631-638. https://doi.org/10.1016/j. jhazmat.2018.08.019

27. Li J, Zhang Y, Wang F, Wang L, Liu J, Hashimoto Y, Hosomi M (2021) Arsenic immobilization and removal in contaminated soil using zero-valent iron or magnetic biochar amendment followed by dry magnetic separation. Sci Total Environ 768:144521. https://doi.org/10.1016/j.scitotenv.2020.144521

28. Burton ED, Hockmann K, Karimian N (2020) Antimony sorption to goethite: effects of $\mathrm{Fe}(\mathrm{II})$-catalyzed recrystallization. ACS Earth Space Chem 4(3):476-487. https://doi.org/10.1021/acsea rthspacechem.0c00013

29. Deng RJ, Jin CS, Ren BZ, Hou BL, Hursthouse AS (2017) The potential for the treatment of antimony-containing wastewater by iron-based adsorbents. Water. https://doi.org/10.3390/w9100794

30. Wang J, Chen Y, Zhang Z, Ai Y, Liu L, Qi L, Zhou J, Hu Z, Jiang R, Bao H, Ren S, Liang J, Sun H, Niu D, Liang Q (2018) Microwell confined iron oxide nanoparticles in honeycomblike carbon spheres for the adsorption of $\mathrm{Sb}(\mathrm{III})$ and sequential utilization as a catalyst. ACS Sustain Chem Eng 6(10):12925-12934. https:// doi.org/10.1021/acssuschemeng.8b02300

31. Tighe M, Lockwood PV, Ashley PM, Murison RD, Wilson SC (2013) The availability and mobility of arsenic and antimony in an acid sulfate soil pasture system. Sci Total Environ 463-464:151160. https://doi.org/10.1016/j.scitotenv.2013.05.032

32. Nakazawa H, Fujisawa H, Sato H (1998) Effect of activated carbon on the bioleaching of chalcopyrite concentrate. Int J Miner Process 55(2):87-94. https://doi.org/10.1016/s0301-7516(98)00026-x

33. Emino E, Warman P (2004) Biological assay for compost quality. Compost Sci Utilization 12:342-348. https://doi.org/10.1080/ 1065657X.2004.10702203

Publisher's Note Springer Nature remains neutral with regard to jurisdictional claims in published maps and institutional affiliations. 


\section{Authors and Affiliations}

\section{L. Álvarez ${ }^{1} \cdot$ G. Gascó ${ }^{2} \cdot$ R. Rodíguez-Pacheco ${ }^{3} \cdot J^{\text {J Paz-Ferreiro }}{ }^{4} \cdot$ A. Méndez ${ }^{1}$}

1 Department of Geological and Mining Engineering, Universidad Politécnica de Madrid, 28040 Madrid, Spain

2 Department of Agricultural Production, Universidad Politécnica de Madrid, Ciudad Universitaria, 28040 Madrid, Spain
3 Instituto Geológico y Minero de España (IGME), Ríos Rosa, 23, 28003 Madrid, Spain

4 School of Engineering, RMIT University, GPO Box 2476, Melbourne, VIC 3001, Australia 